\title{
Male-killing bacterium in a fifth ladybird beetle, Coleomegilla maculata (Coleoptera: Coccinellidae)
}

\author{
GREGORY D. D. HURST*, TANSY C. HAMMARTON, JOHN J. OBRYCKI†, TAMSIN M. \\ O. MAJERUS, LINDA E. WALKER, DOMINIQUE BERTRAND \& MICHAEL E. N. \\ MAJERUS
}

Department of Genetics, Downing Street, Cambridge CB2 3EH, U.K. and †Department of Entomology, lowa State

University, Ames, IA 50011, U.S.A.

\begin{abstract}
Inherited symbionts which selectively cause the death of male hosts are found widely across the Insecta. Previous studies have shown a single, but different micro-organism to be responsible for male-killing in each taxonomic group studied. We here produce evidence that within a group of insects, the Coccinellidae, there is more than one causal agent of male lethality. We report a novel observation of a male-killing trait in the species Coleomegilla maculata. Six of 26 crosses were found to produce a female-biased sex ratio associated with a low egg hatch-rate. The trait was matrilinearly inherited and was observed to be tetracycline-sensitive. However, tests which indicate the presence of a Rickettsia, previously found to cause male-killing in another member of the Coccinellidae, Adalia bipunctata, proved negative. We therefore conclude that the phenomenon of male-killing is multicausal, within, as well as between, taxonomic groups of the Insecta.
\end{abstract}

Keywords: Coleomegilla maculata, female-biased sex ratio, inherited symbiont, male-killing.

\section{Introduction}

Inherited symbionts represent an important feature in the evolution of many species of insect. On one hand, there are many symbionts whose presence has a positive effect on host fitness, through contribution to anabolic pathways within the host. Here, the symbioses are often ancient (around $200 \mathrm{Ma}$ in the case of the Buchnera-aphid symbiosis) and the symbiont may be considered part of the genetic constitution of the host (Moran et al., 1993). On the other hand, there are inherited symbionts which are parasitic. The parasitic actions of these symbionts are often manifested solely in the male line. Because they are inherited almost exclusively through the female, these symbionts have little 'evolutionary interest' in being in a male. Three main types of effect are known: cytoplasmic incompatibility (partial or complete sterility of crosses between infected males and uninfected females), the induction of parthenogenesis (the bacterium promotes thelytoky), and early male-killing (the symbiont kills

*Correspondence. male embryos that it enters). Symbionts with these effects are known across a wide range of insect orders (Hurst, 1991; O'Neill et al., 1992; Stouthamer et al., 1993).

These three types of parasitism are similar in underlying evolutionary rationale, but quite different in their biology. Whereas all known cases of cytoplasmic incompatibility and the induction of parthenogenesis appear to be a product only of bacteria of the genus Wolbachia (Hurst, 1991, 1993; O'Neill et al., 1992; Rousset et al., 1992; Stouthamer et al., 1993; Werren et al., 1995), male-killing is caused by a diverse array of inherited bacteria. The behaviour is exhibited by Spiroplasma symbionts of members of the Drosophila willistoni group (Williamson \& Poulson, 1979), by a symbiont of Adalia bipunctata that is a Rickettsia typhi relative (Werren et al., 1994; Balayeva et al., 1995), and by Arsenophonus nasoniae, a member of the gamma-group of the Proteobacteria found in Nasonia vitripennis (Werren et al., 1986; Gherna et al., 1991). The range of causal agents has made investigation of the diversity of insect species affected by male-killing problematic. Whereas selective PCR amplification has allowed 
workers to search for Wolbachia across diverse taxa, no such search has been possible for male-killing agents.

The search for male-killing agents has therefore continued through case-by-case examination of the sex ratio produced by individual members of different insect species. Candidate hosts are those where there is an obvious evolutionary advantage to a symbiont which causes male death. Sibling egg cannibalism, competition between siblings for resources and inbreeding have all been proposed as host factors that promote the spread of male-killing strains (Skinner, 1985; Werren, 1987; Hurst, 1991; Hurst \& Majerus, 1993). When any of these phenomena are observed, the death of male hosts increases the lifetime reproductive success of sibling females, which owing to common descent bear the same bacterium. Symbionts with male-killing behaviour spread under these conditions, either because the death of male hosts results in a reallocation of resources from the male line (through which the symbiont cannot pass) to the female (through which it can), or because the death of males forces their infected sisters to outbreed (or at least not mate with siblings), thus avoiding the adverse effects of inbreeding depression.

One group which begs investigation in this light are the coccinellid beetles, where sibling egg cannibalism is common. Previous studies have shown coccinellids of four different genera to be infected with maternally inherited male-killing symbionts: $A$. bipunctata (Hurst et al., 1992), Harmonia axyridis (Matsuka et al., 1975), Menochilius sexmaculatus (Niijima \& Nakajima, 1981), and Hippodamia convergens (Shull, 1948). We here investigate the sex ratio produced by crosses of Coleomegilla maculata (DeGeer), a coccinellid which also exhibits sibling egg cannibalism, and in which the survival of neonate larvae is thought to be positively affected by an egg meal (Smith, 1961; Pienkowski, 1965). We report the infection of this species with a malekilling symbiont. We further note that the causal agent of male-killing in this species is different from that in $A$. bipunctata.

\section{Female-biased crosses in C. maculata}

\section{Method}

Coleomegilla maculata adults were collected following overwintering, from Ames, IA, during the spring of 1994. Twenty-six crosses were set up, and the eggs laid by each female removed daily and counted. The number of eggs in each clutch which hatched was recorded, and the progeny were reared to maturity and then sexed. Sex was determined using abdominal morphology; the male has a distinct ventral 'notch' in the posterior margin of the posterior abdominal tergite, through which the penis protrudes during copulation, compared to the more rounded margin of the posterior tergite of the female. Sexing criteria were checked by dissection of the genitals, and found to be 98 per cent accurate $(n=60)$.

\section{Results}

The crosses could be divided into two groups on the basis of sex ratio. Six of the 26 crosses produced significantly female-biased families, whereas the other 20 crosses produced families which did not deviate significantly from the expected one-to-one sex ratio (test for heterogeneity between these two groups: $\chi_{25}^{2}=170.84 ; P<0.001$; neither group shows evidence of internal heterogeneity). The crosses producing families with a female-biased sex ratio also produced eggs with a low hatch-rate (average hatch-rate $=50.2$ per cent; $S E=4.6$ per cent) when compared to those producing a normal sex ratio (average hatch-rate $=86.5$ per cent; $S E=2.4$ per cent). In fact, these six crosses produced eggs with six of the seven lowest hatch-rates of all 26 crosses (Mann-Whitney $U$-test: $U=328.0 ; n_{1}=20, n_{2}=6$; $P<0.001)$ (Table 1)

\section{Inheritance of the trait}

\section{Method}

Crosses were set up between males from normal sex ratio families and females from the later clutches of crosses producing biased sex ratio families. Crosses were also set up between males and females which were both from normal sex ratio families. The egg hatch-rate and sex ratio produced by these crosses were recorded as before.

\section{Results}

All 11 crosses involving females from biased sex ratio clutches produced eggs with low hatch-rates and female-biased families (Table 2a) (summed data, test vs. $1: 1$ sex ratio: $\left.\chi_{1}^{2}=108.9 ; P<0.001\right)$. In contrast, crosses involving females from normal sex ratio families produced eggs with high hatch-rates and families with a normal sex ratio (Table $2 \mathrm{~b}$ ) (summed data, test vs. 1:1 sex ratio: $\chi_{1}^{2}=0.04$; NS). Of the 11 crosses involving females from biased sex 
Table 1 Egg hatch-rate and sex ratio data for matrilines of Coleomegilla maculata. Lines showing a low proportion of eggs developing $(<0.70)$ and a very low proportion of males $(<0.25)$ are shown here in bold type

\begin{tabular}{|c|c|c|c|c|}
\hline Cross & $\begin{array}{l}\text { No. } \\
\text { eggs laid }\end{array}$ & $\begin{array}{l}\text { Proportion } \\
\text { of eggs } \\
\text { developing }\end{array}$ & $\begin{array}{l}\text { No. } \\
\text { progeny } \\
\text { reared }\end{array}$ & $\begin{array}{l}\text { Proportion } \\
\text { male }\end{array}$ \\
\hline Col-1 & 96 & 0.84 & 39 & 0.54 \\
\hline $\mathrm{Col}-2$ & 59 & 0.93 & 19 & 0.58 \\
\hline Col-3 & 80 & 0.94 & 39 & 0.51 \\
\hline Col-4 & 21 & 0.86 & 7 & 0.86 \\
\hline Col-5 & 6 & 0.83 & 3 & 0.67 \\
\hline Col-6 & 78 & 0.43 & 32 & 0.00 \\
\hline Col-7 & 318 & 0.61 & 78 & 0.08 \\
\hline Col-8 & 68 & 0.93 & 19 & 0.58 \\
\hline Col-9 & 94 & 0.95 & 41 & 0.61 \\
\hline Col-10 & 194 & 0.67 & 36 & 0.11 \\
\hline Col-11 & 44 & 0.73 & 13 & 0.46 \\
\hline Col-12 & 101 & 0.91 & 40 & 0.38 \\
\hline Col-14 & 89 & 0.87 & 29 & 0.55 \\
\hline Col-15 & 55 & 0.98 & 24 & 0.38 \\
\hline Col-16 & 113 & 0.91 & 28 & 0.46 \\
\hline Col-17 & 89 & 0.89 & 25 & 0.36 \\
\hline Col-18 & 176 & 0.44 & 52 & 0.06 \\
\hline Col-19 & 23 & 0.74 & 13 & 0.38 \\
\hline Col-20 & 22 & 0.77 & 12 & 0.42 \\
\hline Col-21 & 16 & 0.81 & 7 & 0.43 \\
\hline Col-22 & 184 & 0.47 & 42 & 0.00 \\
\hline Col-23 & 30 & 0.97 & 12 & 0.33 \\
\hline Col-26 & 65 & 0.97 & 32 & 0.47 \\
\hline Col-27 & 120 & 0.54 & 32 & 0.53 \\
\hline Col-29 & 15 & 0.93 & 9 & 0.67 \\
\hline Col-30 & 106 & 0.39 & 25 & 0.00 \\
\hline
\end{tabular}

ratio clutches, five produced some male progeny. The sex ratio and egg hatch-rate of broods produced by these females was heterogeneous over time. Early clutches from these females tended to have higher egg hatch-rates, and were more likely to give rise to males, than later clutches (Table 3).

\section{Conclusion}

Coleomegilla maculata crosses are heterogeneous with respect to the sex ratio they produce, with some individuals producing female-biased families and others producing equal numbers of males and females. The trait is stably inherited (it has now been maintained for five generations in the laboratory), with the lineage of the female dictating the presence of the trait. Within females which produce a biased sex ratio, two types may be discerned. First, there are individuals which never produce male
Table 2 Egg hatch-rate and sex ratio data for crosses involving different Coleomegilla maculata females. The two numbers identifying a cross refer to the source of first the female, then the male. In (a) crosses where males were produced are in bold

\begin{tabular}{|c|c|c|c|c|}
\hline Cross & Eggs laid & $\begin{array}{l}\text { Egg hatch- } \\
\text { rate }\end{array}$ & $\begin{array}{l}\text { Progeny } \\
\text { reared }\end{array}$ & $\begin{array}{c}\text { Proportion } \\
\text { male }\end{array}$ \\
\hline
\end{tabular}

(a) females from each of the six biased sex ratio families

$\begin{array}{lrlll}6.20 & 70 & 0.44 & 25 & 0.00 \\ 7.2 & 93 & 0.39 & 21 & 0.00 \\ 7.9 & 120 & 0.35 & 28 & 0.00 \\ \mathbf{1 0 . 9} & \mathbf{1 8 5} & \mathbf{0 . 4 8} & \mathbf{3 6} & \mathbf{0 . 1 7} \\ \mathbf{1 0 . 1 5} & \mathbf{7 8} & \mathbf{0 . 7 3} & \mathbf{2 3} & \mathbf{0 . 2 6} \\ \mathbf{1 8 . 8} & \mathbf{1 3 3} & \mathbf{0 . 5 3} & \mathbf{4 6} & \mathbf{0 . 0 7} \\ 18.16 & 105 & 0.41 & 23 & 0.00 \\ \mathbf{2 2 . 3} & \mathbf{3 8 0} & \mathbf{0 . 5 6} & \mathbf{7 8} & \mathbf{0 . 2 7} \\ 22.15 & 195 & 0.43 & 36 & 0.00 \\ 30.9 & 85 & 0.38 & 17 & 0.00 \\ \mathbf{3 0 . 2 7} & \mathbf{1 4 6} & \mathbf{0 . 4 2} & \mathbf{3 8} & \mathbf{0 . 1 8}\end{array}$

(b) females from normal sex ratio families

\begin{tabular}{lrrrr}
1.3 & 236 & 0.73 & 62 & 0.56 \\
1.12 & 49 & 0.76 & 21 & 0.33 \\
11.12 & 295 & 0.76 & 83 & 0.48 \\
14.15 & 44 & 0.68 & 14 & 0.57 \\
14.23 & 48 & 0.71 & 6 & 0.50 \\
20.17 & 61 & 0.72 & 19 & 0.37 \\
23.2 & 29 & 0.76 & 11 & 0.64 \\
23.20 & 225 & 0.77 & 65 & 0.48 \\
26.9 & 201 & 0.48 & 38 & 0.61 \\
26.27 & 91 & 0.32 & 9 & 0.33 \\
$27 . \mathrm{E} 8$ & 101 & 0.73 & 12 & 0.50 \\
27.16 & 60 & 0.73 & 20 & 0.40 \\
\hline
\end{tabular}

offspring. Secondly, there are females which produce a mixture of male and female offspring early in their reproductive life, but only female offspring later on. These females might be said to show a 'progressive' sex ratio trait (sensu Hu, 1979).

The production of female-biased families is associated with low egg hatch-rates. Consistent with this is the observation that crosses producing all-female families have an average egg hatch-rate of around half that of normal ones (average egg hatch-rate across both generations of nine full SR crosses $=41$ per cent; average egg hatch-rate across both generations of 32 normal crosses $=80$ per cent), and the observation that in the five individuals above showing the progressive sex ratio trait, alteration in sex ratio was accompanied by alteration in egg hatch-rate, albeit sometimes with a short (up to 7 day) lag. This may be accounted for if male death 
Table 3 Clutch-by-clutch detail of the hatch-rate and sex ratio of the five sex ratio crosses of Coleomegilla maculata producing some male progeny. Grey eggs are those in which the embryos developed fully, were visible through the chorion, but failed to hatch

\begin{tabular}{|c|c|c|c|c|c|c|c|c|c|c|c|c|c|c|c|c|c|c|c|}
\hline \multirow[b]{2}{*}{ Cross } & & \multicolumn{18}{|c|}{ Clutch } \\
\hline & & 1 & 2 & 3 & 4 & 5 & 6 & 7 & 8 & 9 & 10 & 11 & 12 & 13 & 14 & 15 & 16 & 17 & 18 \\
\hline \multirow[t]{6}{*}{10.9} & Date & $16 / 7$ & $18 / 7$ & $20 / 7$ & $23 / 7$ & $25 / 7$ & $28 / 7$ & $30 / 7$ & $2 / 8$ & $7 / 8$ & $18 / 8$ & $20 / 8$ & $24 / 8$ & $31 / 8$ & & & & & \\
\hline & Size & 6 & 13 & 20 & 18 & 6 & 18 & 3 & 10 & 22 & 7 & 28 & 10 & 24 & & & & & \\
\hline & No. hatched & 4 & $?$ & 7 & 15 & 3 & 12 & 2 & 6 & 8 & 4 & 13 & 3 & 6 & & & & & \\
\hline & No. grey & 0 & $?$ & 4 & 3 & 1 & 4 & 0 & 3 & 5 & 0 & 2 & 1 & 2 & & & & & \\
\hline & No. males & 1 & 0 & 1 & 3 & 1 & 0 & 0 & 0 & 0 & 0 & 0 & 0 & 0 & & & & & \\
\hline & No. females & 1 & 2 & 3 & 2 & 2 & 1 & 0 & 2 & 1 & 3 & 7 & 1 & 5 & & & & & \\
\hline \multirow[t]{6}{*}{10.15} & Date & $13 / 7$ & $23 / 7$ & $30 / 7$ & $11 / 8$ & $14 / 8$ & $22 / 8$ & & & & & & & & & & & & \\
\hline & Size & 10 & 21 & 10 & 20 & 14 & 3 & & & & & & & & & & & & \\
\hline & No. hatched & 10 & 15 & 7 & 17 & 7 & 1 & & & & & & & & & & & & \\
\hline & No. grey & 0 & 2 & 0 & 1 & 2 & 0 & & & & & & & & & & & & \\
\hline & No. males & 1 & 4 & 1 & 0 & 0 & 0 & & & & & & & & & & & & \\
\hline & No. females & 1 & 5 & 1 & 3 & 6 & 1 & & & & & & & & & & & & \\
\hline \multirow[t]{6}{*}{18.8} & Date & 9/7 & $12 / 7$ & $26 / 7$ & $5 / 8$ & $13 / 8$ & $17 / 8$ & $20 / 8$ & $24 / 8$ & $26 / 8$ & $30 / 8$ & $31 / 8$ & $6 / 9$ & & & & & & \\
\hline & Size & 10 & 11 & 1 & 3 & 21 & 9 & 24 & 14 & 7 & 15 & 15 & 3 & & & & & & \\
\hline & No. hatched & 7 & 11 & 1 & 3 & 11 & 5 & 13 & 6 & 3 & 7 & 2 & 1 & & & & & & \\
\hline & No. grey & 1 & 0 & 0 & 0 & 2 & 3 & 0 & 0 & 1 & 0 & 0 & 0 & & & & & & \\
\hline & No. males & 1 & 2 & 0 & 0 & 0 & 0 & 0 & 0 & 0 & 0 & 0 & 0 & & & & & & \\
\hline & No. females & 2 & 1 & 1 & 3 & 5 & 4 & 13 & 4 & 2 & 5 & 2 & 1 & & & & & & \\
\hline \multirow[t]{6}{*}{22.3} & Date & $10 / 7$ & $13 / 7$ & $15 / 7$ & $22 / 7$ & $23 / 7$ & $25 / 7$ & $26 / 7$ & $27 / 7$ & $30 / 7$ & $2 / 8$ & $8 / 8$ & $12 / 8$ & $15 / 8$ & $18 / 8$ & $20 / 8$ & $22 / 8$ & $29 / 8$ & $6 / 9$ \\
\hline & Size & 11 & 19 & 26 & 13 & 18 & 17 & 17 & 13 & 17 & 19 & 36 & 24 & 18 & 27 & 22 & 32 & 27 & 24 \\
\hline & No. hatched & 4 & 14 & 12 & 11 & 18 & 17 & 17 & 13 & 15 & 11 & 26 & 9 & 2 & 11 & 6 & 7 & 10 & 11 \\
\hline & No. grey & 2 & 2 & 2 & 1 & 0 & 0 & 0 & 0 & 0 & 3 & 1 & 7 & 8 & 15 & 6 & 13 & 1 & 0 \\
\hline & No. males & 0 & 4 & 3 & 2 & 4 & 3 & 1 & 0 & 0 & 0 & 4 & 0 & 0 & 0 & 0 & 0 & 0 & 0 \\
\hline & No. females & 2 & 4 & 1 & 1 & 2 & 6 & 1 & 1 & 1 & 3 & 2 & 4 & 1 & 5 & 5 & 8 & 7 & 3 \\
\hline \multirow[t]{6}{*}{30.27} & Date & $16 / 9$ & $24 / 9$ & $28 / 9$ & $30 / 9$ & $4 / 10$ & $7 / 10$ & $11 / 10$ & $12 / 10$ & $13 / 10$ & $16 / 10$ & $17 / 10$ & $20 / 10$ & & & & & & \\
\hline & Size & 2 & 12 & 11 & 11 & 19 & 13 & 15 & 11 & 10 & 18 & 11 & 13 & & & & & & \\
\hline & No. hatched & 1 & 10 & 6 & 8 & 9 & 5 & 5 & 4 & 3 & 2 & 1 & 7 & & & & & & \\
\hline & No. grey & 0 & 0 & 5 & 1 & 5 & 7 & 3 & 0 & 0 & 7 & 2 & 0 & & & & & & \\
\hline & No. males & 1 & 2 & 1 & 3 & 0 & 0 & 0 & 0 & 0 & 0 & 0 & 0 & & & & & & \\
\hline & No. females & 0 & 3 & 3 & 2 & 5 & 4 & 3 & 2 & 3 & 1 & 0 & 5 & & & & & & \\
\hline
\end{tabular}

occurs at first in the early larval stage, but later develops into mortality of male embryos. This correlation between sex ratio and egg hatch-rate strongly suggests that the sex ratio distortion is a product of male-death.

\section{Progressive sex ratio trait: inheritance by females derived from initial clutches}

\section{Method}

Crosses were set up involving females derived from early-laid clutches (from which both male and female individuals were reared) from each of the five 'progressive' sex ratio crosses described above. The sex ratios and egg hatch-rates in clutches produced by these crosses were monitored.

\section{Results}

Crosses involving females from early-laid clutches from progressive sex ratio families produced eggs showing high hatch-rates and families with a normal sex ratio (Table 4). No progression to a femalebiased sex ratio was seen in the two months during which these crosses remained reproductively active.

\section{Conclusion}

Females showing the progressive sex ratio trait do not transmit the trait to all their progeny. The clutches laid early in the life of these females (which produce both males and females) contain daughters that do not display the trait.

(C) The Genetical Society of Great Britain, Heredity, 77, 177-185. 


\section{Nature of the trait: antibiotic sensitivity}

\section{Method}

The susceptibility of the trait to antibiotics was tested as described by Hurst et al. (1992). In short, the $F_{1}$ females above showing the sex ratio trait (Table 2a) were allowed to feed daily for $1 \mathrm{~h}$ over a period of 14 days upon either tetracycline in golden syrup (10 per cent $w / w)$, or golden syrup alone. Individuals showing a normal sex ratio and high egg hatch-rate were also treated with the diet of tetracycline in golden syrup, to control against any endogenous effects of antibiotics on sex ratio and egg hatch-rate. The hatch-rate of eggs and the sex ratio of the resultant family were monitored. Female progeny of biased sex ratio, antibiotic-treated females after the completion of treatment were also treated with tetracycline in the same way, because it has been shown that treatment across two successive generations increases the chances of complete cure (Breeuwer \& Werren, 1993). Again, the hatch-rate

Table 4 Egg hatch-rate and sex ratio data for crosses involving early conceived females from five 'progressive' sex ratio crosses of Coleomegilla maculata

\begin{tabular}{lcccc}
\hline Cross & Eggs laid & $\begin{array}{c}\text { Egg hatch- } \\
\text { rate }\end{array}$ & $\begin{array}{c}\text { Progeny } \\
\text { reared }\end{array}$ & $\begin{array}{c}\text { Proportion } \\
\text { male }\end{array}$ \\
\hline Col R-1 & 129 & 0.86 & 56 & 0.48 \\
Col R-2 & 45 & 0.64 & 3 & 0.33 \\
Col R-3 & 190 & 0.76 & 52 & 0.48 \\
Col R-4 & 161 & 0.69 & 45 & 0.51 \\
Col R-5 & 51 & 0.30 & 14 & 0.43 \\
\hline
\end{tabular}

Col R-1, 10.15 $F_{1}$ female $\times 27 . E 8 F_{1}$ male; Col R-2, 22.3 $F_{1}$ female $\times 23.20 \mathrm{~F}_{1}$ male; Col R-3, 18.8 $\mathrm{F}_{1}$ female $\times$ Col 17 $F_{1}$ male; Col R-4, 10.9 $F_{1}$ female $\times 27 . E 8 F_{1}$ male; Col $R-5,30.27 F_{1}$ female $\times 20.17 F_{1}$ male. of eggs and the sex ratio of progeny produced were recorded.

\section{Results}

The egg hatch-rates of sex ratio females of both generations allowed to feed upon tetracycline in golden syrup increased, and males were produced in the families of these individuals following treatment (Table 5). The proportion of males produced by the second generation of treated females was approximately one half, i.e. these females had reverted to the production of a normal 1:1 sex ratio (Table 6). Neither sex ratio females allowed to feed upon golden syrup lacking tetracycline, nor normal females allowed to feed upon golden syrup bearing tetracycline, showed any significant changes in egg hatch-rate or the sex ratio of the family produced (Tables 7 and 8) (analysis of sex ratio changes on summed data: (i) initially biased sex ratio crosses; $\chi_{1}^{2}=0.0$; NS; (ii) initially unbiased sex ratio crosses: $\chi_{1}^{2}=3.4 ; \mathrm{NS}$ ).

Table 6 Egg hatch-rates and sex ratio data for $F_{1}$ females (post-tetracycline) from each of the four biased sex ratio lines of Coleomegilla maculata

\begin{tabular}{lcccc}
\hline Cross & $\begin{array}{c}\text { Eggs } \\
\text { laid }\end{array}$ & $\begin{array}{c}\text { Egg } \\
\text { hatch-rate }\end{array}$ & $\begin{array}{c}\text { Progeny } \\
\text { reared }\end{array}$ & $\begin{array}{c}\text { Proportion } \\
\text { male }\end{array}$ \\
\hline AB-1 & 144 & 0.83 & 45 & 0.53 \\
$\mathrm{AB}-2$ & 63 & 0.71 & 23 & 0.48 \\
$\mathrm{AB}-3$ & 31 & 0.58 & 6 & 0.50 \\
$\mathrm{AB}-4$ & 76 & 0.83 & 28 & 0.46 \\
\hline
\end{tabular}

AB-1, 18.8 $F_{1}$ female $\times 26.27 F_{1}$ male; AB-2, 7.9 $F_{1}$ female $\times 14.15 F_{1}$ male; AB-3, 30.27 $F_{1}$ female $\times 14.15 F_{1}$ male; AB-4, $10.15 F_{1}$ female $\times 1.3 F_{1}$ male.

Table 5 Egg hatch-rates and sex ratios produced by four biased sex ratio crosses of Coleomegilla maculata following treatment with tetracycline. Pre-tetracycline data were calculated from the last six egg clutches produced prior to the start of treatment

\begin{tabular}{cccllc}
\hline & \multicolumn{2}{c}{ Pre-tetracycline } & & \multicolumn{2}{c}{ Post-tetracycline } \\
\cline { 2 - 3 } \cline { 5 - 6 } Cross & $\begin{array}{c}\text { Egg } \\
\text { hatch-rate }\end{array}$ & $\begin{array}{c}\text { Sex ratio } \\
\text { (proportion male) }\end{array}$ & & $\begin{array}{c}\text { Egg } \\
\text { hatch-rate }\end{array}$ & $\begin{array}{c}\text { Sex ratio } \\
\text { (proportion male) }\end{array}$ \\
\hline 7.9 & $0.36(n=86)$ & $0.00(n=19)$ & & $0.70(n=98)$ & $0.29(n=24)$ \\
10.15 & $0.68(n=78)$ & $0.00(n=23)$ & & $0.40(n=111)$ & $0.32(n=22)$ \\
18.8 & $0.41(n=78)$ & $0.00(n=27)$ & & $0.48(n=27)$ & $0.20(n=10)$ \\
30.27 & $0.28(n=78)$ & $0.00(n=14)$ & $0.63(n=172)$ & $0.40(n=47)$ \\
\hline
\end{tabular}

$n$, sample size. 
Table 7 Egg hatch-rates and sex ratios produced by biased sex ratio lines of Coleomegilla maculata following treatment with golden syrup. Data were calculated as described in Table 5

\begin{tabular}{llcllc}
\hline & \multicolumn{2}{c}{ Pre-golden syrup } & & \multicolumn{2}{c}{ Post-golden syrup } \\
\cline { 5 - 6 } \cline { 5 - 6 } Cross & $\begin{array}{c}\text { Egg } \\
\text { hatch-rate }\end{array}$ & $\begin{array}{c}\text { Sex ratio } \\
\text { (proportion male) }\end{array}$ & & $\begin{array}{c}\text { Egg } \\
\text { hatch-rate }\end{array}$ & $\begin{array}{c}\text { Sex ratio } \\
\text { (proportion male) }\end{array}$ \\
\hline 10.9 & $0.44(n=101)$ & $0.00(n=19)$ & & $0.38(n=71)$ & $0.00(n=19)$ \\
18.16 & $0.41(n=73)$ & $0.00(n=18)$ & & $0.43(n=89)$ & $0.00(n=15)$ \\
22.3 & $0.31(n=150)$ & $0.00(n=29)$ & & $0.36(n=151)$ & $0.00(n=31)$ \\
30.9 & $0.38(n=85)$ & $0.00(n=17)$ & & $0.26(n=102)$ & $0.00(n=12)$ \\
\hline
\end{tabular}

$n$, sample size.

Table 8 Egg hatch-rates and sex ratios produced by normal sex ratio lines of Coleomegilla maculata following treatment with tetracycline

\begin{tabular}{cccllc}
\hline & \multicolumn{2}{c}{ Pre-tetracycline } & & \multicolumn{2}{c}{ Post-tetracycline } \\
\cline { 6 - 7 } Cross & $\begin{array}{c}\text { Egg } \\
\text { hatch-rate }\end{array}$ & $\begin{array}{c}\text { Sex ratio } \\
\text { (proportion male) }\end{array}$ & & $\begin{array}{c}\text { Egg } \\
\text { hatch-rate }\end{array}$ & $\begin{array}{c}\text { Sex ratio } \\
\text { (proportion male) }\end{array}$ \\
\hline 1.3 & $0.70(n=86)$ & $0.50(n=31)$ & & $0.58(n=122)$ & $0.57(n=46)$ \\
11.12 & $0.71(n=138)$ & $0.43(n=51)$ & & $0.63(n=27)$ & $0.62(n=13)$ \\
20.17 & $0.73(n=56)$ & $0.35(n=17)$ & & $0.83(n=90)$ & $0.58(n=40)$ \\
23.20 & $0.68(n=113)$ & $0.42(n=43)$ & & $0.66(n=157)$ & $0.46(n=52)$ \\
26.9 & $0.48(n=100)$ & $0.53(n=19)$ & & $0.58(n=31)$ & $0.55(n=11)$ \\
26.27 & $0.32(n=87)$ & $0.38(n=8)$ & $0.39(n=74)$ & $0.62(n=13)$ \\
\hline
\end{tabular}

$n$, sample size.

\section{Conclusion}

The sex ratio trait was seen to be sensitive to tetracycline in golden syrup, but not to golden syrup alone, producing a permanent reversion to a $1: 1$ sex ratio. The sensitivity of the trait to an antibiotic strongly suggests that the causal agent is bacterial in nature.

\section{Causative agent: test for presence of Rickettsia}

\section{Method}

Extraction of genomic DNA DNA was extracted by phenol-chloroform extraction followed by ethanol precipitation. Abdomens of adult females were placed in $1.5 \mathrm{~mL}$ Eppendorf tubes and frozen in liquid nitrogen. Sterile digestion buffer $(250 \mu \mathrm{L}$; $80 \mathrm{~mm}$ EDTA, 1 per cent SDS, $160 \mathrm{~mm}$ sucrose and $100 \mathrm{~mm}$ Tris $\mathrm{HCl}, \mathrm{pH} 8.0$ ) and $2.5 \mu \mathrm{L}$ proteinase $\mathrm{K}$ $(30 \mathrm{mg} / \mathrm{mL})$ were added, the ladybird was ground up using a sterile pipette tip and the mixture was left at $37^{\circ} \mathrm{C}$ overnight or at $65^{\circ} \mathrm{C}$ for $2 \mathrm{~h}$. A $50: 50$ mixture of phenol-chloroform $(250 \mu \mathrm{L})$ was added, the solution shaken for $2 \mathrm{~min}$, and the phases separated by 10 min microcentrifugation. This step was repeated using a 1 volume aliquot of chloroform. DNA was ethanol precipitated, washed in 70 per cent ethanol, resuspended in $100 \mu \mathrm{L}$ sterile water and stored at $-20^{\circ} \mathrm{C}$.

\section{Amplification of the rickettsial $17 \mathrm{kDa}$ antigen gene using PCR}

\section{Method}

PCR was employed to amplify 434 bases of the $17 \mathrm{kDa}$ antigen gene common to members of the typhi group of the genus Rickettsia using the primers described by Williams et al. (1992), which are specific for the Rickettsia group (forward primer: 5'-GCTCTTGCAACTTCTATGTT-3'; reverse primer: 5'-CATTGTTCGTCAGGTTGGCG-3'). A volume of $1 \mu \mathrm{L}$ of a tenfold dilution of the genomic 
DNA to be tested was added to a reaction mixture containing $5 \mu \mathrm{L} 10 \times \mathrm{NH}_{4}$ buffer (Bioline, London, U.K.), $5 \mu \mathrm{L}$ of nucleotide mixture $(2.5 \mathrm{~mm}$ each of dATP, dTTP, dGTP and dCTP; Pharmacia, Biotech, St Albans, U.K.), $2.5 \mu \mathrm{L} 50 \mathrm{~mm} \mathrm{MgCl}_{2}, 50$ pmole of each primer, 1 unit Taq polymerase (Bioline) and sterile distilled water to give a final volume of $50 \mu \mathrm{L}$. PCR cycling conditions in a HYBAID OmniGene PCR machine were as follows: 1 cycle of $1 \mathrm{~min}$ at $94^{\circ} \mathrm{C}, 1 \mathrm{~min}$ at $57^{\circ} \mathrm{C}$ and $1 \mathrm{~min}$ at $72^{\circ} \mathrm{C} ; 35$ cycles of $15 \mathrm{~s}$ at $92^{\circ} \mathrm{C}, 1 \mathrm{~min}$ at $57^{\circ} \mathrm{C}$ and $1 \mathrm{~min}$ at $70^{\circ} \mathrm{C} ; 1$ cycle of $15 \mathrm{~s}$ at $92^{\circ} \mathrm{C}, 1 \mathrm{~min}$ at $57^{\circ} \mathrm{C}$, and $5 \mathrm{~min}$ at $70^{\circ} \mathrm{C}$. Amplification controls were run for the PCR cocktail, for template DNA from known Rickettsiainfected insects, and for template DNA from known uninfected $C$. maculata. PCR products were visualized using UV light following electrophoresis on a 1.2 per cent agarose gel containing ethidium bromide.

\section{Results}

A product of around $440 \mathrm{bp}$ was obtained from both reactions containing genomic DNA from $A$. bipunctata infected with the male-killing Rickettsia (the positive control), as expected from previous studies. Such a product was not obtained when the genomic DNA added was derived from uninfected $A$. bipunctata (negative control), nor when genomic DNA derived from sex ratio $C$. maculata individuals was added, nor further when genomic DNA from normal C. maculata lines was added (Fig. 1).

\section{Conclusion}

The failure of rickettsial-specific PCR amplification demonstrates that the $C$. maculata male-killing bacterium does not belong to the typhi group of the genus Rickettsia. This reaction has been shown to be robust across this group of the genus Rickettsia, but produces no product with either members of the tsutsugamushi group of this genus, nor with bacteria outside of this group (Williams et al., 1992; Balayeva et al., 1995) The reaction consistently amplifies the Cambridge $A$. bipunctata male-killer. Thus, we may conclude that the male-killer in $C$. maculata is different from the male-killer present in $A$. bipunctata.

\section{Discussion}

This investigation has demonstrated the presence of a male-killing trait in C. maculata, which, like other male-killing traits, is heritable through the female

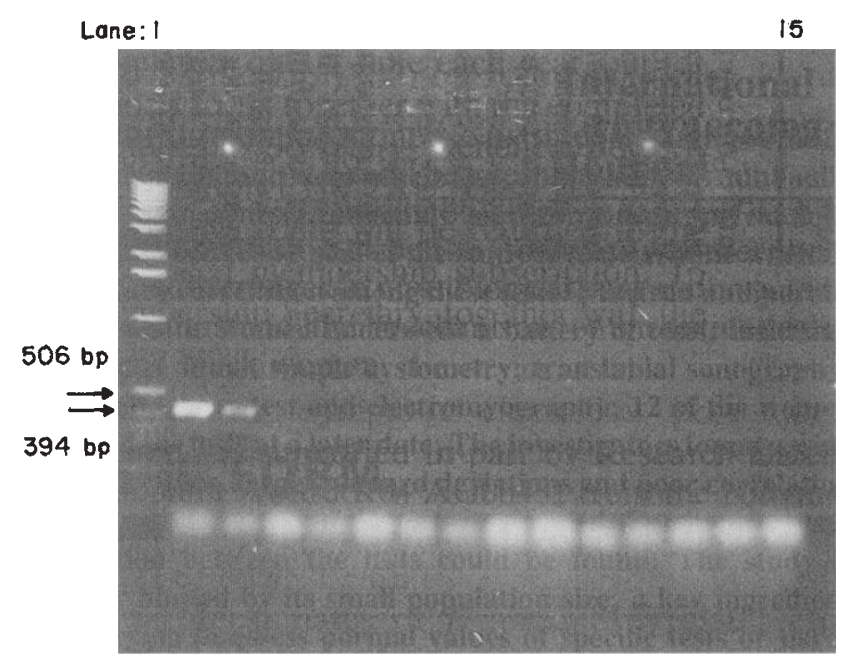

Fig. 1 Results of PCR amplification of the rickettsial $17 \mathrm{kDa}$ gene using differing genomic DNA templates as described in the text. Lane 1, $1 \mathrm{~kb}$ DNA ladder (BRL); lanes 2-3, template from Cambridge Adalia bipunctata infected with Rickettsia; lanes 4-5, template from Cambridge $A$. bipunctata uninfected with Rickettsia; lanes 6-11, template from Coleomegilla maculata SR lines; lanes 12-14, template from C. maculata normal lines; lane 15 , water control.

line and is curable with antibiotics. The causative agent of male-killing is distinct from the male-killing agent found in $A$. bipunctata, but has yet to be identified. It had previously been recognized that malekilling is multicausal between taxonomic groups, but this is the first instance where male-killing within a single taxonomic group (in this case, the Coccinellidae) has been shown to be of multiple origins. If this observation, that male-killing is multicausal within as well as between groups, is generally true, then malekilling behaviour will have evolved independently many times. Male-killing, unlike cytoplasmic incompatibility, appears to be a bacterial trait that has evolved independently in different symbionts in many host species both within and between groups of insects.

The observation that male-killing has evolved many times has important consequences for our general understanding of the evolutionary biology of symbiont-host interactions. That many symbionts may evolve male-killing behaviour suggests that symbiont-host interactions are more prone to evolve to this state than was previously recognized. It is likely that male-killing is a relatively simple trait to evolve, involving inducement of some pathogenic response following a cue of host sex (Hurst, 1993). This contrasts to the 'Wolbachia' phenomena of cytoplasmic incompatibility and parthenogenesis 
induction, which involve subtle manipulations of host chromosome behaviour at mitosis (Breeuwer \& Werren, 1990; Stouthamer et al., 1993). It remains to be seen whether all incidences of male-killing follow a similar mechanistic theme. Only detailed study of the interaction between symbiont and host will allow this question to be resolved. This study also provides insight into the population biology of male-killing elements. With perfect vertical transmission, a malekiller will go to fixation, causing the extinction of both it and its host. Infidelity of transmission prevents this increase to fixation, constantly creating uninfected lineages. In the $C$. maculata system, infidelity of vertical transmission is associated with the frequent absence of the trait early in the reproductive cycle of the host. In females displaying this progressive sex ratio trait, early clutches show good hatchability, and the female progeny raised from these clutches do not themselves show the trait. The progressive nature of the trait presumably reflects a build up in bacterial number within the host to some critical density. It is tempting to speculate that the progressive trait indicates that the symbiont has to fight to enter the germ-line, and is perhaps a reflection of a host-parasite conflict over transmission, as has been documented in the Wolbachia-Armadillidium vulgare symbiosis (Rigaud \& Juchault, 1992).

The existence of the progressive trait also suggests an interesting way in which selection could act upon the host to decrease the transmission of the parasite. If a sex ratio trait takes time to develop, selection may favour speeded development to reproductive maturity, for this would widen the window in which the parasite is not transmitted to progeny. In short, the presence of a male-killing bacterium which transmitted to progeny with increasing efficiency over time would be expected to result in selection on the host for precocious reproductive development. Inherited parasites may produce selection upon host life history.

Beyond this widening of our perspective of symbiont-host interactions, the finding of a male-killer in C. maculata also alters our perception of the frequency with which insects are infected with malekilling symbionts. The discovery of a male-killing bacterium in $C$. maculata brings the number of coccinellid genera (and species) known to harbour male-killers to five, and suggests that there may be many more genera and species that do so. The thesis that the presence of sibling egg cannibalism in members of this group has rendered them very prone to invasion by male-killing symbionts (Hurst et al., 1992; Hurst \& Majerus, 1993) appears to be corroborated. In addition, the fact that $C$. maculata is a species which has been well-worked in the laboratory over a period of more than 20 years suggests that many more species of coccinellid may be infected with male-killing bacteria than previously thought. The fact that a species has been intensively studied without report of a male-killer clearly cannot be taken as evidence of absence of a male-killer. Male-killing may be extremely common within the Coccinellidae, and other groups where male-killing is advantageous to symbionts.

\section{Acknowledgements}

We wish to thank Dr Simon Collier and Professor Michael Ashburner for advice and loan of equipment, and Mr Alan Feast and Mr Roger Day for technical support. This work was carried out in a laboratory built with the support of the Wolfson Foundation. We wish to thank Christ's College, Cambridge (G. H.), the Wellcome Foundation and the Balfour Browne Fund (T. H.), and the NERC (grant GR 9/993 to M. M.) for financial support.

\section{References}

BALAYEVA, N. M., EREMEEVA, M. E., TISSOT-DUPONT, H., ZAKHAROV, I. A. AND RAOULT, D. 1995. Genotype characterization of the bacterium expressing the malekilling trait in the ladybird beetle Adalia bipunctata with specific Rickettsial molecular tools. Appl. Env. Microbiol., 61, 1431-1437.

BREEUWER, J. A. J. AND WERREN, J. H. 1990. Microorganisms associated with chromosome destruction and reproductive isolation between two insect species. Nature, 346, 558-560.

BREEUWER, J. A. J. AND WERREN, J. H. 1993. Effect of genotype on cytoplasmic incompatibility between two species of Nasonia. Heredity, 70, 428-436.

GHERNA, R. L., WERREN, J. H., WEISBURG, W., COTE, R., WOESE, C. R., MANDELCO, L. AND BRENNER, D. J. 1991. Arsenophonus nasoniae gen.-nov., sp.-nov., the causative agent of the son killer trait in the parasitic wasp Nasonia vitripennis. Int. J. Syst. Bact., 41, 563-565.

HU, K. 1979. Maternally inherited 'sonless' abnormal SR condition in the ladybeetle Harmonia axyridis. Acta Genet. Sinica, 6, 296-304.

HURST, G. D. D. AND MAJERUS, M. E. N. 1993. Why do maternally inherited microorganisms kill males? Heredity, 71, 81-95.

HURST, G. D. D., MAJERUS, M. E. N. AND WALKER, L. E. 1992. Cytoplasmic male killing elements in Adalia bipunctata (Linnaeus) (Coleoptera: Coccinellidae). Heredity, 69, 84-91.

HURST, L. D. 1991. The incidences and evolution of cytoplasmic male killers. Proc. $R$. Soc. B, 244, 91-99.

HURST, L. D. 1993. The incidences, mechanisms and evolu- 
tion of cytoplasmic sex ratio distorters in animals. Biol. Rev., 68, 121-193.

MATSUKA, M., HASHI, H. AND OKADA, I. 1975. Abnormal sex-ratio found in the lady beetle, Harmonia axyridis Pallas (Coleoptera: Coccinellidae). Appl. Ent. Zool., 10, 84-89.

MORAN, N. A., MUNSON, M. A., BAUMANN, P. AND ISHIKAWA, H. 1993. A molecular clock in endosymbiotic bacteria is callibrated using the insect hosts. Proc. R. Soc. B, 253, 167-171.

NIIJIMA, K. AND NAKAJIMA, K. 1981. Abnormal sex ratio in Menochilius sexmaculatus (Fabricius). Bull. Fac. Agric. Tamagawa Univ., 21, 59-67.

O'NEILL, S. L., GIORDANO, R., COLBERT, A. M. E., KARR, T. L. AND ROBERTSON, H. M. 1992. 16S rRNA phylogenetic analysis of the bacterial endosymbionts associated with cytoplasmic incompatibility in insects. Proc. Natl. Acad. Sci. U.S.A., 89, 2699-2702.

PIENKOWSKI, R. L. 1965. The incidence and effect of egg cannibalism in first instar Coleomegilla maculata lengi (Coccinellidae). Ann. Entomol. Soc. Am., 58, 150-153.

RIGAUD, T. AND JUCHAULT, P. 1992. Genetic control of the vertical transmission of a cytoplasmic sex factor in Armadillidium vulgare. Heredity, 68, 47-52.

ROUSSET, F., BOUCHON, D., PINTUREAU, B., JUChaUlt, P. AND SOLIGNAC, M. 1992. Wolbachia endosymbionts responsible for various alterations of sexuality in arthropods. Proc. R. Soc. B, 250, 91-98.

SHULL, H. F. 1948. An all-female strain of lady beetles with reversion to normal sex ratios. Am. Nat., 82, 241-251.

SKINNER, s. w. 1985. Son-killer: a third extrachromosomal factor affecting sex ratios in the parasitoid wasp
Nasonia vitripennis. Genetics, 109, 745-754.

SMITH, B. C. 1961. Influence of water and previous food on the longevity of unfed larvae of Coleomegilla maculata lengi. J. Econ. Entomol., 54, 194-195.

STOUTHAMER, R., BREEUWER, J. A. J., LUCK, R. F. AND WERREN, J. H. 1993. Molecular identification of organisms associated with parthenogenesis. Nature, 361, $66-68$.

WERREN, J. H. 1987. The coevolution of autosomal and cytoplasmic sex ratio factors. J. Theor. Biol., 124, 317-334.

WERREN, J. H., SKINNER, S. W. AND HUGER, A. M. 1986. Male-killing bacteria in a parasitic wasp. Science, 231, 990-992.

WERREN, J. H., HURST, G. D. D., ZHANG, W., BREEUWER, J. A. J., STOUTHAMER, R. AND MAJERUS, M. E. N. 1994. Rickettsial relative associated with male killing in the ladybird beetle (Adalia bipunctata). J. Bacteriol., 176, 388-394.

WERREN, J. H., ZHANG, W. AND GUO, L. R. 1995. Evolution and phylogeny of Wolbachia: reproductive parasites of arthropods. Proc. R. Soc. B, 261, 55-71.

WILLIAMS, S. G., SACCI, J. B. J., SCHRIEFER, M. E., ANDERSEN, E. M., FUJIOKA, K. K., SORVILlO, F. J., BARR, A. R. AND AZAD, A. F. 1992. Typhus and typhuslike rickettsiae associated with opposums and their fleas in Los Angeles. J. Clin. Microbiol., 30, 1758-1762.

WILliAMSON, D. L. AND POULSON, D. F. 1979. Sex ratio organisms (Spiroplasmas) of Drosophila. In: Whitcomb, R. F. and Tully, J. G. (eds) The Mycoplasmas, pp. 175-208. Academic Press, New York. 